\title{
Egg production of Acartia bifilosa in the small temperate estuary of Mundaka, Spain, in relation to environmental variables and population development
}

\author{
I. Uriarte, U. Cotano, F. Villate* \\ Landare-Biologia eta Ekologia Saila, Zientzi Fakultatea, Euskal Herriko Unibertsitatea, P.K. 644, E-48080 Bilbao, Spain
}

\begin{abstract}
Egg production was determined for the copepod Acartia bifilosa, and related to environmental variables, female carbon budget, and population growth during the spring-summer-autumn period of 1994 and 1995 in the estuary of Mundaka, Spain. Field incubations were made with natural water and adult females collected in the polyhaline zone of the estuary. Chlorophyll ingestion rates of adult females were estimated using the balance method in 1995. The female carbon budget was evaluated by assuming indirect estimations of respiration, phytoplankton carbon, and assimilation efficiency. Egg production rate was found to be higher in spring (maximal mean of $32.6 \mathrm{egg}$ female ${ }^{-1} \mathrm{~d}^{-1}$ ) and lower in autumn (minimal mean of $6.7 \mathrm{egg}$ female $\mathrm{e}^{-1} \mathrm{~d}^{-1}$ ), but the 2 years examined were quite different in terms of egg production and the relationships of egg production to temperature and chlorophyll. Egg production related positively with temperature in general, but maximal values occurred at intermediate temperatures; this suggests a non-linear relationship. The relationship between egg production and phytoplankton biomass (expressed as chlorophyll concentration) was not clear, probably because there was no food limitation. Estimates of daily carbon intake based on chlorophyll ingestion rates (between 28.2 and $228.8 \mathrm{ng}$ chl female ${ }^{-1} \mathrm{~d}^{-1}$ on average) indicate that a herbivorous diet could satisfy carbon requirements and support egg production by $A$. bifilosa females most of the time. Population peaked in summer, after spring maximal egg production rates occurred, but population abundance in the second year was higher while egg production was lower. As seasonal and between-year differences in reproductive rates and population growth were not adequately explained by the measured environmental variables, the likely effect of other factors and mechanisms is discussed
\end{abstract}

KEY WORDS: Acartia bifilosa $\cdot$ Copepods $\cdot$ Egg production - Estuaries

\section{INTRODUCTION}

The copepod Acartia bifilosa is found inhabiting a wide range of brackish-water habitats along the Atlantic and Mediterranean European shores and is a dominant species in mesohaline waters of the Baltic Sea (Viitasalo 1992a), the polyhaline and mesohaline regions of large estuaries such as the Severn (Collins \& Williams 1981), the Gironde (Castel 1981), the Forth (Taylor 1987) and the Ems (Baretta \& Malschaert 1988), and some shallow Mediter ranean lagoons (LamHoai 1985), among others. Therefore, it is assumed

\footnotetext{
•E-mail:gvpvigul@lg.ehu.es
}

that $A$. bifilosa shows a great adaptability to different brackish-water environments, but little is known concerning its biological response to these various environments in terms of productivity.

In large estuaries this species appears seaward of the usually dominant Eurytemora species, which are found to have the highest copepod density in such estuaries (e.g. Sautour \& Castel 1995). Among the small estuaries of the eastern Cantabrian coast of the Bay of Biscay, however, Eurytemora species are absent and Acartia bifilosa is found to be the main autochthonous brackish-water copepod (Villate \& Orive 1981, San Vicente et al. 1988, Villate 1991),

The estuary of Mundaka $(\sim 13 \mathrm{~km}$ long and $2.5 \mathrm{~m}$ mean depthj is one of these small shallow systems of 
the inner Bay of Biscay that are characterized by strong seasonal and short-term environmental changes. There is usually a high degree of hydrological stability in summer because of low and regular freshwater inflows. The Acartia bifilosa population reaches the annual maximum during this time (Villate et al. 1993). However, as freshets are frequent from autumn to early spring, substantial short-term alterations of the hydrological conditions and plankton dynamics result, and under such conditions the $A$. bifilosa population may become negligible (Madariaga et al. 1992).

The general objectives of this study were (1) to obtain quantitative information on the reproductive rate of Acartia bifilosa in the estuary of Mundaka, and (2) to determine possible links between the fecundity of $A$. bifilosa and environmental factors, taking the female carbon budget and population developments into account.

\section{MATERIALS AND METHODS}

Sampling. Two sampling series were carried out in the estuary of Mundaka in 1994 and 1995. Samples were taken in order to cover the productive part of the seasons in the estuary, from late winter to mid-autumn.

Sampling and experiments were conducted during $2 \mathrm{~d}$ visits to the estuary. In 1994, egg production of Acartia bifilosa was evaluated by means of in situ experiments on 19-20 May, 15-16 June, 9-10 and 28-29 July, 21-22 September, 13-14 October and 9-10 November. Sampling on 19 April revealed no A. bifilosa individuals in mesozooplankton samples. In 1995, in situ experiments for the determination of egg production and algal feeding by adult females were made on 2-3 and 30-31. May, 26-27 June, 10-11 and 24-25 July, 13-14 September, 9-10 October and 6-7 November.

Sampling was carried out during the day and copepods were incubated over a $24 \mathrm{~h}$ period to ensure minimal disturbance during the most active spawning times, which occur at night (e.g. Cervetto et al. 1993, Landry et al. 1994).

Water was collected at mid-depth (around $1.5 \mathrm{~m}$ below the surface) using $30 \mathrm{l}$ hydrological bottles (Van Dorn type) and was transferred to three 25 l carboys using a large tube that was immersed in the carboy to minimize splashing and bubbling. In the third carboy we added mesozooplankton collected with a $200 \mu \mathrm{m}$ net at the same site, depth and time. Water temperature and salinity were immediately measured in the carboys with a portable thermosalinometer.

The content of 2 carboys was screened with $200 \mu \mathrm{m}$ Nytal mesh to obtain a quantitative mesozooplankton sample. The sample was preserved in buffered $4 \%$ formalin. The content of the third carboy including the concentrated sample of mesozooplankton was used for the in situ experiments of egg production and herbivory

Experimental procedure. The mesozooplankton contained in the third carboy was gently concentrated in a collector with a $200 \mu \mathrm{m}$ Nytal mesh. Water for incubations was filtered through a 45 um mesh to remove all the metazoan zooplankton and copepod eggs, and dispensed into six 0.51 bottles. Then, 6 to 15 (usually 8) undamaged and actively swimming adult females were sorted from the mesozooplankton sample and placed into each bottle. In addition, in the 1995 experiments, 2 bottles were filled with the screened water, but without Acartia bifilosa, to be used as controls in the herbivory experiments.

Incubations were conducted in the field. Bottles were placed horizontally into coarse mesh bags and suspended from a frame supported by floats at a central point in the channel. Incubations were conducted at $1.5 \mathrm{~m}$ depth from the surface, for $24 \mathrm{~h}$. After incubation, the content of the bottles was screened through 200 and $45 \mu \mathrm{m}$ meshes to remove and quantify the incubated individuals and eggs.

In 1995, levels of initial and final fluorescence in control and experimental bottles were measured with a Turner Designs fluorometer. After the initial screening processes to remove mesozooplankton and microplankton and after incubations were completed, a part of the water was also filtered through $\mathrm{GF} / \mathrm{F}$ filters These GF/F filters were frozen $\left(-60^{\circ} \mathrm{C}\right)$ for later determination of chlorophyll a concentration by fluorometric methods. Chlorophyll a fluorescence in $90 \%$ acetone extracts was measured on a Shimadzu RF-540 fluorometer, according to the method of Lorenzen (1967).

Analysis of females and eggs. The size and number of eggs and the prosome length of females were measured under an inverted Olympus microscope equipped with a measurement reticule.

Female dry weight $\left(\mu \mathrm{g}_{\text {ind }} \mathrm{-}^{-1}\right)$ was measured from 3 replicate groups of 40 individuals for each sampling day. After having been rinsed briefly with deionized water to remove salt, samples were dried at $60^{\circ} \mathrm{C}$ for $24 \mathrm{~h}$ and combusted at $450^{\circ} \mathrm{C}$. A M3P Sartorius electrobalance was used to obtain weight values. Dry weights were corrected for weight loss due to preservation $(22 \%)$ (Smith \& Lane 1985). Body carbon weight of females ( $\mathrm{\mu g} \mathrm{C}$ ind ${ }^{-1}$ ) was estimated from female dry weight by assuming a carbon content of $45 \%$ (Kiørboe \& Nielsen 1.994)

Egg carbon was estimated from egg diameter by assuming a perfect sphericity of eggs and a carbon:volume content of $0.14 \times 10^{-6} \mu \mathrm{g} \mathrm{C} \mathrm{m}^{-3}$ (Huntley \& Lopez 1992, Kiørboe \& Nielsen 1994\}. 
Egg production. Daily egg production (eggs ind $\left.{ }^{-1} \mathrm{~d}^{-1}\right)$ was calculated as $[(E+N) / F]$ $\times 24 / T$, where $E=$ number of eggs, $N=$ number of nauplii, $F=$ number of females, and $T=$ incubation time (h). Egg cannibalism was not observed in experimental bottles because when empty shells were found they corresponded to hatched nauplii. To explain egg production in carbon units ( $\mu \mathrm{g} \mathrm{C}$ ind ${ }^{-1}$ $\mathrm{d}^{-1}$ ) we used the egg carbon content estimated from egg diameter. The specific egg production rate was calculated from the estimated egg carbon and female body carbon.

Feeding. Ingested chlorophyll was evaluated using the balance method (Omori \& Ikeda 1984), which is based on differences in chlorophyll concentrations of control and experimental bottles. Ingested chlorophyll was expressed as carbon ( $\mathrm{\mu g} \mathrm{C}$ ) by assuming a C:chl a ratio of 50 (Baldwin \& Newell 1995, Landry et al. 1995), and a minimal possible ratio of 20 (Peterson \& Festa 1984).

Respiration and energetic requirements. Female respiration expressed in carbon units $\left(\mu \mathrm{g} \mathrm{C}\right.$ ind. ${ }^{-1} \mathrm{~d}^{-1}$ ) was estimated from individual body weight and temperature according to the equation of Ikeda (1985).

Carbon requirements were derived from egg production by assuming that the ingested carbon per female must be 3 times as much as the carbon used in egg production (Kiorboe et al. 1985).

\section{RESULTS}

\section{Environmental variables and Acartia bifilosa population dynamics}

Seasonal variations in water temperature, chlorophyll a content and Acartia bifilosa abundance are presented in Fig. 1, together with precipitation data for the watershed of the estuary. The rainfall data are shown to illustrate variations in freshwater inputs, since the maximum volume of freshwater within the estuary appears 1 to $2 \mathrm{~d}$ after the maximum rainfall in the watershed (Madariaga et al. 1992).

Periods of high precipitation were observed in April and September 1994, and from Decernber 1994 to March 1995. From late winter to the end of 1995, however, rainfall remained moderate or low. High temperatures were recorded in summer $\left(22\right.$ to $24^{\circ} \mathrm{C}$ in July), and between-year differences were only remarkable in early spring, when temperature was clearly lower in $1994\left(11\right.$ to $16^{\circ} \mathrm{C}$ ) than in 1995 (around $18^{\circ} \mathrm{C}$ ). Chlorophyll peaked in spring in both years, but the spring maximum was higher in $1994\left(19.8 \mathrm{\mu g} \mathrm{l}^{-1}\right.$ as compared to $8.4 \mathrm{~kg} \mathrm{l}^{-1}$ in 1995), while autumn values were higher

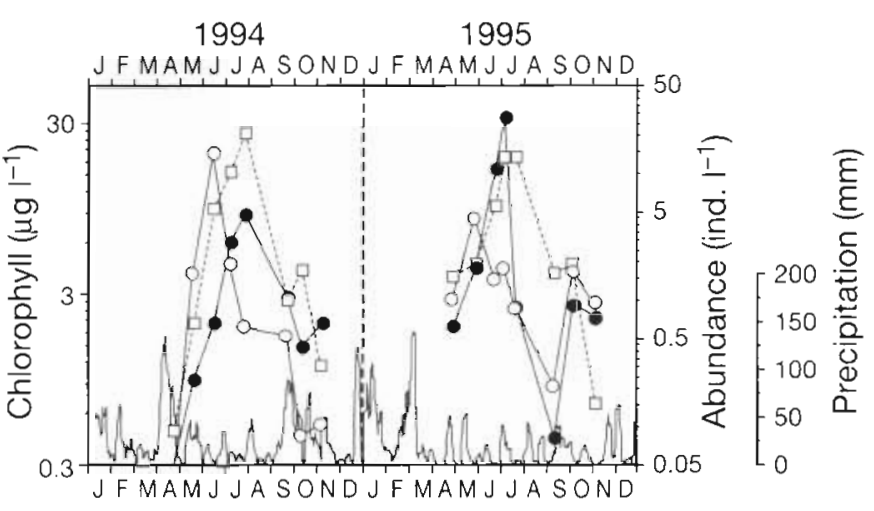
1995

Fig. 1. Variations in water temperature (D), chlorophyll a concentration (o), abundance of Acartia bifilosa in the mesozooplankton fraction ( ) and accuestuary of Mundaka in 1994 and 1995

in 1995. Acartia bifilosa populations peaked in July in both years, but densities in spring and early summer were higher in 1995 (a maximum of 28.0 ind. $1^{-1}$ as compared to a maximum of 4.9 ind. $\mathrm{l}^{-1}$ in 1994), while late summer densities were higher in 1994. It should also be pointed out that $A$. bifilosa was not found in the zooplankton samples taken in April 1994 and that the population decreased drastically in late summer 1995.

\section{Females and egg size}

As shown in Fig. 2, prosome length and weight of adult females were generally less in summer. Longer

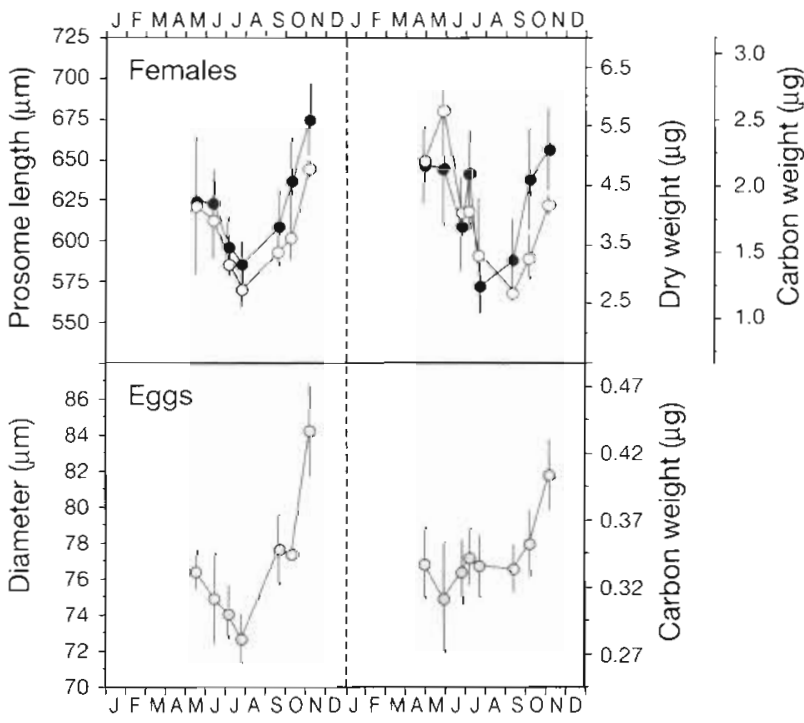

Fig. 2. Acartia bifilosa. Variations in female prosome length $(\bullet)$, dry weight and calculated carbon weight $(0)$, and egg diameter and calculated carbon content $(0)$ in the estuary of Mundaka in 1994 and 1995. Mean values (circles) and standard deviation (vertical lines) 
females were recorded in late autumn (mean of around $675 \mu \mathrm{m}$ ) but the biggest ones corresponded to spring 1995 (mean of $5.78 \mu \mathrm{g}$ ). Between years, the dry weight of spring-summer females was higher in 1995, while the dry weight of autumn females was higher in 1994. In that year, the smallest values for prosome length and weight coincided in July $(586 \mu \mathrm{m}$ and $2.75 \mu \mathrm{g}$, respectively). In 1995, however, female length was also the smallest in July $(572 \mu \mathrm{m})$ but female weight was the smallest in September $(2.68 \mu \mathrm{g})$.

Eggs obtained in late autumn were larger (mean diameter values of 84.2 and $81.8 \mu \mathrm{m}$ in 1994 and 1995 , respectively) than those obtained in spring-summer $(<78 \mu \mathrm{m}$ in both years), but between-year differences in egg size were also noticeable. Egg size showed a seasonal trend with the lowest value in summer $(72.3 \mu \mathrm{m})$ during 1994, while no clear seasonal variations were observed in egg size during the spring-summer period (mean values between 74.9 and $78.0 \mu \mathrm{m}$ ) in 1995 .

\section{Egg production and respiration of females}

Higher egg production values were recorded in spring and early summer, mainly in 1994, although a low value was obtained in late May 1995 (Fig. 3). Between years, the mean egg production rate was higher in 1994 (9.5 to 32.5 egg female ${ }^{-1} \mathrm{~d}^{-1}$ ) than in 1995 (6.7 to 16.5 egg female $\mathrm{f}^{-1} \mathrm{~d}^{-1}$ ).

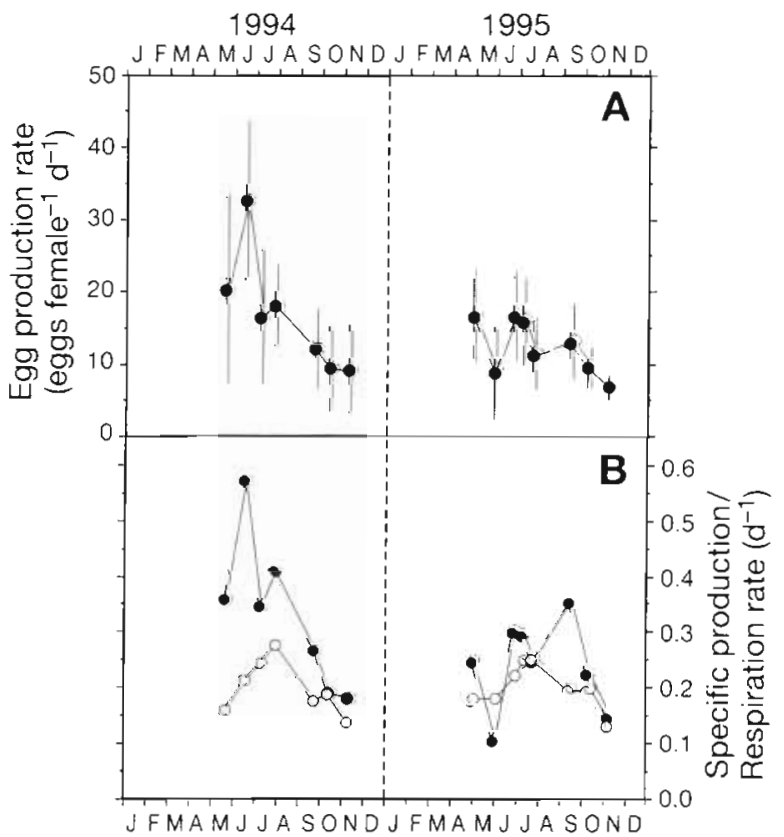

Fig. 3. Acartia bifilosa. Variations in (A) egg production rate and $(B)$ estimated specific production $(\bullet)$ and respiration $(O)$ rates, expressed as ddily body carbon of females in the estuary of Mundaka in 1994 and 1995. Mean values (circles) and standard deviation (vertical lines)
The calculated specific production (per female body carbon) ranged from 0.18 to $0.57 \mathrm{~d}^{-1}$ in 1994 and from 0.10 to $0.35 \mathrm{~d}^{-1}$ in 1995 , while respiration varied between 0.13 (November) and 0.25 to $0.28 \mathrm{~d}^{-1}$ (July) of the female body carbon. However, in 1994 the highest specific production coincided with the highest egg production rate in late spring (June), while in 1995 the highest specific production was obtained in early autumn (September), whereas the highest egg production rate occurred in April and June.

\section{Phytoplankton feeding and assimilation}

Experiments conducted in 1995 showed that the chlorophyll ingestion rate of Acartia bifilosa females was closely related to chlorophyll availability in natural waters (Fig. 4). Ingestion rates ranged on average from $28.2 \mathrm{ng}$ chl female $\mathrm{d}^{-1}$, with low chlorophyll availability $\left(0.88 \mathrm{Hg} \mathrm{l}^{-1}\right.$ ) in September, to $228.8 \mathrm{ng} \mathrm{chl}$ female $\mathrm{d}^{-1}$, with high chlorophyll availability $(8.41 \mu \mathrm{g}$ $1^{-1}$ ) in May.

The estimated phytoplankton-carbon ingestion, based on C:chl ratios of 50 and 20, was higher than the estimated carbon requirement in most cases (Table 1). Carbon requirements were sometimes found to be higher than carbon ingested only when a C:chl ratio of 20 in phytoplankton food was assumed.

\section{Between-variables relationships}

As shown in the linear correlation matrix for the measured environmental and biological variables (Table 2), size-related variables (female length, female dry weight and egg diameter) showed a very signifi-

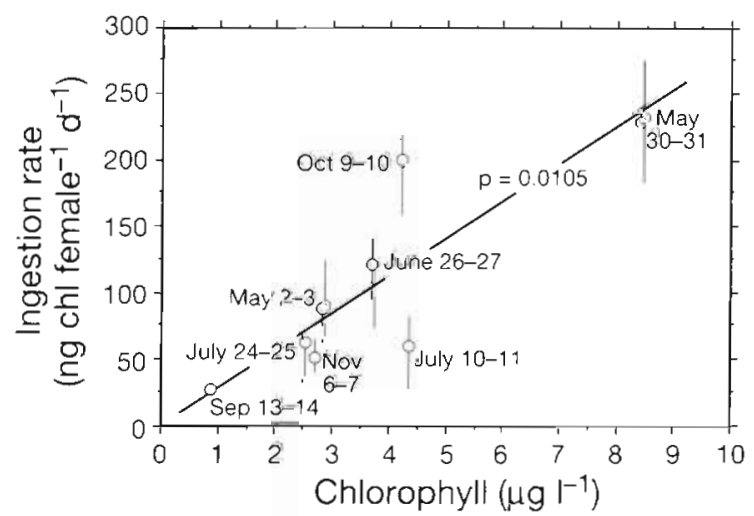

Fig. 4. Acartia bifilosa. Relationship between chlorophyll ingestion rate of females (mean value: $O_{i}$ values range: vertical line) and chlorophyll content in natural waters of the estuary of Mundaka, based on experiments carried out in 1995. Continuous line is the regression through all the replicates 
Table 1 Acartia bifilosa. Calculated individual requirement and ingestion of carbon by females in the estuary of Mundaka in 1995. Carbon requirements were derived from egg production and ingestion of carbon from chlorophyll ingestion data and values of $\mathrm{C}: \mathrm{chl}$ ratios taken from the literature (explanation in text)

\begin{tabular}{|c|c|c|c|}
\hline Date & $\begin{array}{c}\text { Requirement } \\
\left(\mu \mathrm{g} C \text { female } \mathrm{fem}^{-1} \mathrm{~d}^{-1}\right)\end{array}$ & \multicolumn{2}{|c|}{ Ingestion ( $\mu \mathrm{g} C$ female ${ }^{-1} \mathrm{~d}^{-1}$ ) } \\
\hline May 2-3 & 1.51 & 1.76 & 4.40 \\
\hline May 30-31 & 0.75 & 4.58 & 11.44 \\
\hline Jun $26-27$ & 1.51 & 2.43 & 6.08 \\
\hline Jul 10-11 & 1.48 & 1.17 & 2.92 \\
\hline Jul 24-25 & 1.02 & 1.22 & 3.84 \\
\hline Sep 13-14 & 1.18 & 0.56 & 1.41 \\
\hline Oct $9-10$ & 0.91 & 3.96 & 9.90 \\
\hline Nov $6-7$ & 0.75 & 0.98 & 2.46 \\
\hline
\end{tabular}

cant $(p<0.01)$ or significant $(p<0.05)$ negative correlation with temperature in 1994, but not in 1995. These variables, however, were not well correlated with chlorophyll in general. Chlorophyll only showed a positive significant correlation with female weight for the 1995 data set.

Egg production rate and specific production were correlated positively with chlorophyll concentration in $1994(p<0.01)$, but not in 1995. For the total data set, only egg production rate showed a significant

Table 2. Acartia bifilosa. Correlation matrix for measured abiotic variable (water temperature, $\mathrm{T}^{\circ} \mathrm{C}$ ) and biotic variables (chlorophyll content, chl $a_{i}$ female prosome length, FPL female dry weight, FDW; egg diameter, ED; egg production rate, EPR; and specific egg production, SEP). Correlation coefficients were obtained separately from each data set corresponding to 1994 and 1995, and from total data. $(\cdot p<0.05, \cdots p<0.01)$

\begin{tabular}{|c|c|c|c|c|c|c|}
\hline & $\mathrm{T}$ & Chl a & FPL & FDW & $\mathrm{ED}$ & EPR \\
\hline \multicolumn{7}{|c|}{$1994(n=7)$} \\
\hline Chl a & 0.401 & & & & & \\
\hline FPL & $-0.824^{\circ}$ & -0.339 & & & & \\
\hline FDW & $-0.841 \cdots$ & $\cdot-0.065$ & $0.926^{\circ}$ & & & \\
\hline$E D$ & $-0.878 \cdots$ & $\cdot-0.482$ & $0.917^{\prime}$ & $0.845^{\circ}$ & & \\
\hline EPR & 0.434 & $0.959 \cdots$ & $\cdot-0.324$ & -0.071 & -0.521 & \\
\hline SEP & 0.599 & $0.928 \cdot$ & $\cdot-0.498$ & -0.266 & -0.646 & 0.973 \\
\hline \multicolumn{7}{|c|}{$1995(n=8)$} \\
\hline Chl a & 0.151 & & & & & \\
\hline FPL & -0.518 & 0.544 & & & & \\
\hline FDW & -0.158 & $0.756^{\circ}$ & 0.641 & & & \\
\hline ED & -0.653 & -0.284 & 0.356 & -0.231 & & \\
\hline EPR & 0.575 & -0.165 & -0.189 & -0.032 & -0.461 & \\
\hline SEP & 0.480 & -0.658 & -0.577 & $-0.684^{\circ}$ & -0.231 & $0.726^{\circ}$ \\
\hline \multicolumn{7}{|c|}{ Total (n=15) } \\
\hline Chl a & 0.302 & & & & & \\
\hline FPL & $-0.657^{*}$ & 0.004 & & & & \\
\hline FDW & -0.398 & 0.286 & $0.728^{\circ}$ & & & \\
\hline $\mathrm{ED}$ & $-0.758 \cdot \cdot$ & $\cdot-0.416$ & $0.657^{\prime} \cdot$ & 0.316 & & \\
\hline EPR & 0.414 & $0.626^{\circ}$ & -0.256 & -0.122 & $-0.516^{\circ}$ & \\
\hline SEP & 0.479 & 0.421 & -0.487 & -0.476 & $-0.534^{\circ}$ & $0.920^{\circ}$ \\
\hline
\end{tabular}

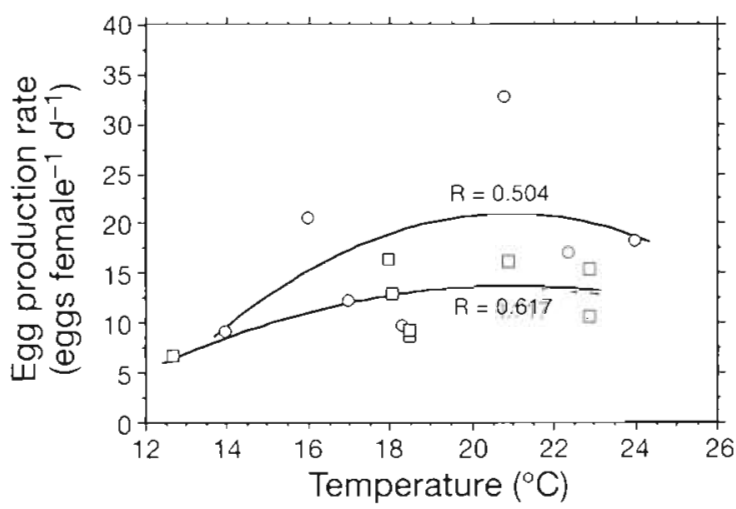

Fig. 5. Acartia bifilosa. Relationship between water temperature and mean egg production rate of females in the estuary of Mundaka in 1994 (O) and 1995 ( $\square$ ). Superimposed on the plot are the fitted lines

$(p<005)$ positive correlation with chlorophyll. Linear correlations between egg produclion and temperature were not significant. However, the plot of egg production against temperature indicates that these variables might be fitted by a polynomial function (Fig. 5), since the highest levels of production were obtained at intermediate temperatures.

Egg production rate was not related to egg diameter, female prosome length and female weight for the 1994 and 1995 data sets, and specific egg production only showed a significant correlation with female weight for the 1995 data set. However, both egg production rate and specific production showed a significant $(p<0.05)$ negative correlation with egg diameter for the total data set.

\section{DISCUSSION}

\section{Egg production and environmental variables}

Seasonal variations in egg production rate did not track the water temperature cycle, and there was no clear relationship between seasonal egg production and chlorophyll concentration. The lack of parallel seasonal variations in egg production and temperature may be in agreement with the likely non-linear relationships between temperature and egg production. Such non-linear relationships appear common to several species of Acartia, whose egg production is found to increase with temperature to some maximum level, then to decline at higher temperatures (Sekiguchi et al. 1980, Uye 1981, White \& Roman 1992). Although egg production rate closely tracked seasonal variations in chlorophyll in 1994, the 1995 results showed no consistent cause-effect relationship between amount of chlorophyll and egg production. In addition, results on 
chlorophyll ingestion and calculations of chlorophyll requirements obtained in 1995 suggest that food limitation was improbable.

Several field studies indicate that the effect of temperature is more important than the effect of chlorophyll on a seasonal scale, while spawning activity is mainly related to ambient chlorophyll concentrations on shorter time scales (e.g. Ambler 1985, 1986, Peterson 1985, Beckman \& Peterson 1986, Kiørboe et al. 1988, Uye \& Shibuno 1992, Bautista et al. 1994). This, however, was not so clear in our study, perhaps because neither temperature nor chlorophyll alone can adequately predict egg production rates on a seasonal scale (Rodriguez et al. 1995). On the other hand, the low egg production rate obtained in late May 1995, when chlorophyll peaked and temperature exceeded $18^{\circ} \mathrm{C}$, indicates that these 2 factors are not sufficient to fully account for egg production rate variations. Many unknown factors such as the availability of nonphotosynthetic food might be involved. There are reports stating that Acartia species prefer ciliates over phytoplankton (Stoecker \& Sanders 1985, Wiadnyana $\&$ Rassoulzadegan 1989) and that their egg production is enhanced by ciliate feeding (Stoecker \& Egloff 1987, White \& Roman 1992, Lonsdale et al. 1996). In our case, no information was obtained on non-photosynthetic food. However, parallel experiments to determine nanozooplankton herbivory in 1995 (Cotano et al. 1998) indicate that heterotrophic protists peaked together with phytoplankton biomass in late May, just when the surprisingly low egg production rate occurred

Other possible sources of variability in daily per capita rates of egg production include intrinsic changes in adult female population, for example, variations in the relative abundance levels of pre-reproductive, reproductive and post-reproductive stages (Ohman et al. 1996). Although this aspect was not analysed in the present study, we found that females occurring in late May 1995 clearly differed in mean weight (the highest throughout the study period) when compared with females of similar mean prosome length which we sampled during other periods.

\section{Egg production and female and egg sizes}

The egg production rate was found to be independent of female length and weight (nearly null correlation). However, it is surprisingly that a weak (not significant) and null relationship between female length and weight and temperature was found in 1995, when in contrast, there was a significant correlation between female weight and chlorophyll. This might be attributed, in part, to the lack of data for winter, when the lowest temperatures and biggest females can be expected. But these findings corroborate the supposition that, although temperature is a dominant factor determining the size of copepods, food conditions may also have a significant influence on body size, primarily on length-specific body weight (Klein Breteler \& Gonzalez 1982, 1988). On the other hand, betweenyear differences in the body size seasonal variation pattern of Acartia bifilosa and other copepod species have been also reported by Viitasalo et al. (1995), who found that the inverse relationship between water temperature and copepod body size may disappear in an interannual context.

Egg size correlated positively with female size (with both prosome length and weight), except for 1995 data. Positive correlations between egg and female size in copepods have been mentioned in the literature (e.g. Uye \& Shibuno 1992). As egg size correlated negatively with temperature, this allows us to suppose that egg size will be significantly larger in winter, when the annual minimum temperature is expected. The fact that egg size also correlated negatively with egg production rate and specific egg production (statistically significant for the total data set), agrees with the reproductive strategy of directing more energy towards egg size rather than egg number to increase reproductive success when food availability decrease (Gisande et al. 1996).

\section{Egg production and female energetic budget}

In oceanic marine environments it is generally suggested than phytoplankton ingestion cannot satisfy carbon demands in copepods (and mesozooplankton in general) which need to derive energy from food other than phytoplankton to sustain egg production and metabolism (Baars \& Fransz 1984, Dam et al. 1995. Prestidge et al. 1995, Zhang et al. 1995). The same is suggested for Acartia bifilosa in the Iarge turbid estuary of Gironde (Irigoien et al. 1996). However, based on the range of values for egg production and estimates of respiration and phytoplankton ingestion/ assimilation we support the hypothesis that $A$. bifilosa was not food limited in the estuary of Mundaka, at least not during the spring-summer-autumn periods analysed.

Assuming a C:chl of 50, the calculated amount of phytoplankton carbon ingested by carbon body weight (mean: $323 \%$, range: 200 to $600 \%$ ) was much higher than values reported for this species in the Gironde estuary (Irigoien \& Castel 1995), and for other Acartia species under laboratory and field conditions (Kiørboe et al. 1985, Durbin \& Durbin 1992, Wlodarczyk et al. 1992), but in the same range of maximum ingestion 
rates obtained for $A$. tonsa under standardized temperature and food conditions (Thompson et al. 1994). The total carbon ingested as phytoplankton could not satisfy the estimated daily carbon demands if the lowest C:chl ratio found in the literature $(\mathrm{C}: \mathrm{chl}=20)$ is assumed. In such a case, limitation also seems improbable taking into account the fact that the assimilation rate in copepods seems to be inversely related to food availability and may be as high as $80 \%$ at low food levels (Kiørboe et al. 1985). Moreover, a hypothetical carbon deficit from phytoplankton ingestion might be easily made up by ingestion of small zooplankton or detritus. The ingestion of heterotrophic nano- and microplankton by Acartia species, including A. bifilosa, is well documented (e.g. Stoecker \& Sanders 1985, Wianyana \& Rassoulzadegan 1989, White \& Roman 1992, Gasparini \& Castel 1997).

The amount of carbon spent on reproduction by Acartia bifilosa females in the estuary of Mundaka during the study period (equivalent to $10-60 \%$ of body carbon daily) falls into the range of values observed in the literature for the congeneric species $A$. tonsa in other estuarine habitats (Ambler 1985, Kiørboe et al. 1985, Kleppel 1992).

\section{Egg production and population development}

The finding of higher egg production rates in spring and higher population densities in summer suggests that there is a temporal mismatch between reproductive rate and population abundance for Acartia bifilosa similar to that described for other copepods (Ianora \& Buttino 1990, Ianora et al. 1992). This seasonal pattern of egg production and abundance for $A$. bifilosa in the polyhaline region of the estuary of Mundaka also agrees with the statement by Kiørboe \& Nielsen (1994) that - based on the coincidence of the vernal increase in biomass with the spring production burst - copepod biomass is related to the seasonal variation in copepod production.

Between-year differences in abundance levels and temporal variations, however, indicate that not only the reproductive rate but also other causal agents were necessary to explain the observed population changes. The absence of individuals in April 1994 could be attributed to advective losses during the period of high precipitation. Salinity zonation corroborated a sudden seaward displacement of low salinity water in the estuary due to the effects of a river flood. In fact, oligohaline waters $(0.5$ to $5 \%$ ) filled the inner half of the estuary, and polyhaline waters reached the mouth at high tide on 19 April. Under such conditions, the tidal exchange also favours the transport of autochthonous zooplankton outward from the estuary, since the mean tidal prism:volume ratio is higher than 1 in this system (Villate et al. 1989). Given that Acartia bifilosa is a resting egg spawner (Viitasalo 1992b), the population seems able to recuperate in the water column by hatching from sediments, although the annual development in 1994 appeared limited by the initial low population density in spring. In contrast, the decline in the A. bifilosa population in mid-summer 1995 cannot be attributed to hydrological perturbations. As the most noticeable event in this period was the high abundance of the mysid Mesopodopsis slabberi in the polyhaline region of the estuary, we suppose that the decrease in $A$. bifilosa was due mainly to predation. Mysids may exert high predation pressure on copepod nauplii, copepodites and adults and control populations of brackish copepod species (Aaser et al. 1995, Jerling \& Wooldridge 1995). M. slabberi was also present in 1994 but at a much lower density than in 1995, most likely as a result of the high hydrological instability in early spring 1994 that also affected the annual development of $A$. bifilosa.

\section{CONCLUSIONS}

The egg production by Acartia bifilosa in the estuary of Mundaka was found to be higher in spring, but temperature and phytoplankton biomass (stated as chlorophyll content) were insufficient to fully account for its variations. The relationship between egg production rate and temperature seems to be better expressed by a polynomial function rather than by a linear function. Changes in phytoplankton biomass and egg production did not show a consistent relationship, probably because algal food availability is usually above limiting levels or because food other that phytoplankton was consumed. A relationship between fertility and female size was not proved on a seasonal scale, perhaps due to the lack of data for winter. However, a likely relationship between egg production and egg size was observed, suggesting that under unfavorable conditions egg production decreases but egg size increases. Population maxima in summer followed spring maxima in egg production, both decreasing in autumn. However, the observed between-year differences suggest that both fertility and population growth patterns may be hard to predict in this estuary due to the year-to-year variability in environmental conditions.

Acknowledgements. This study was supported in a part by the Department of Presidency of the Basque Government within the Programme for Aquitaine-Euskadi-Navarre cooperation. We also thank Astilleros de Murueta S.A. for the facilities provided for the field work. Finally, we are grateful to the anonymous reviewers for their useful reviews. 


\section{LITERATURE CITED}

Aaser HF (1995) Seasonal dynamics of the mysid Neomysis integer and its predation on the copepod Eurytemora affinis in a shallow hypertrophic brackish lake. Mar Ecol Prog Ser 127:47-56

Ambler JW (1985) Seasonal factors affecting egg production and variability of eggs of Acartia tonsa Dana from East lagoon, Galveston, Texas. Estuar Coast Shelf Sci 20 $743-760$

Ambler JW (1986) Effect of food quantity and quality on egg production of Acartia tonsa Dana from East lagoon, Galveston, Texas. Estuar Coast Shelf Sci 23:183-196

Baars MA, Fransz HG (1984) Grazing pressure of copepods on the phytoplankton stock of the Central North Sea. Neth J Sea Res 18:120-142

Baldwin BS, Newell RIE (1995) Feeding rate responses of oyster larvae (Crassostrea virginica) to seston quantity and composition. J Exp Mar Biol Ecol 189:77-91

Baretta JW, Malschaert JFP (1988) Distribution and abundance of the zooplankton of the Ems estuary (North Sea). Neth J Sea Res 22:69-81

Bautista B, Harris RP, Rodriguez V, Guerrero F (1994) Temporal variability in copepod fecundity during two different spring bloom periods in coastal waters off Plymouth (SW England). J Plankton Res 16:1367-1377

Beckman BR, Peterson WT (1986) Egg production by Acartia tonsa in Long Island Sound. J Plankton Res 8:917-925

Castel J (1981) Aspects de l'étude écologique du zooplankton de l'estuaire de la Gironde. Oceanis 6:535-577

Cervetto G, Gaudy R, Pagano M, Saint-Jean L, Verriopoulos G. Arfi R, Leveau $M$ (1993) Diel variations in $A$. tonsa feeding, respiration and egg production in a Mediterranean coastal lagoon. J Plankton Res 15:1207-1228

Collins NR, Williams R (1981) Zooplankton of the Bristol Channel and Severn Estuary: the distribution of four copepods in relation to salinity. Mar Biol 64:273-283

Cotano U, Uniarte I. Villate F (1998) Herbivory of nanozooplankton in polyhaline and euhaline zones of a small temperate system (Estuary of Mundaka): seasonal variations. J Exp Mar Biol Ecol (in press)

Dam HG, Zhang X, Butler M, Roman MR (1995) Mesozooplankton grazing and metabolism at the equator in the central Pacific: implications for carbon and nitrogen fluxes. Deep Sea Res II 42:735-756

Durbin EG, Durbin AG (1992) Effects of temperature and food abundance on grazing and short-time weight change in the marine copepod Acartia hudsonica. Limnol Oceanogr $37: 361-378$

Gasparini S, Castel J (1997) Autotrophic and heterotrophic nanoplankton in the diet of the estuarine copepods Eurytemora affinis and Acartia bifilosa. J Plankton Res 19:877-890

Gisande C, Sánchez J, Maneiro I, Miranda A (1996) Tradeoff between offspring number and offspring size in the marine copepod Euterpina acutifrons at different food concentrations. Mar Ecol Prog Ser 143:37-44

Huntley ME, Lopez MDG (1992) Temperature-dependent production of marine copepods: a global synthesis. Am Nat. 140:201-242

Ianora A, Buttino I (1990) Seasonal cycles in population abundances and egg production rates in the planktonic copepods Centropages typicus and Acartia clausi. J Plankton Res $12: 4.73-481$

Ianora A, Mazzocchi MG, Grottoli R (1992) Seasonal fluctuations in fecundity and hatching success in the planktonic copepod Centropages typicus. J Plankton Res 14:1483-1494
Ikeda T. (1985) Metabolic rates of epipelagic marine zooplankton as a function of body size and temperature. Mar Biol 104:1-11

Irigoien X, Castel J (1995) Feeding rates and productivity of the copepod Acartia bifilosa in a hıghly turbid estuary: the Gironde (SW France). Hydrobiologia 311:115-125

Irigoien X, Castel J, Gasparini S (1996) Gut clearance rate as predictor of food limitation situations Application to two estuarine copepods: Acartia bifilosa and Eurytemora affinis. Mar Ecol Prog Ser 131:159-163

Jerling HL, Wooldridge TH (1995) Feeding of two mysid species on plankton in a temperate South African estuary. J Exp Mar Biol Ecol 188:243-259

Kiørboe T, Møhlenberg F, Hamburger K (1985) Bioenergetics of the planktonic copepod Acartia tonsa: relation between feeding, egg production and respiration, and composition of specific dynamic action. Mar Ecol Prog Ser 26:85-97

Kiørboe T, Mohlenberg F, Tiselius P (1988) Propagation in marine planktonic copepods: production and mortality of eggs. In: Boxshall GA, Schminke HK (eds) Biology of copepods. Kluwer Academic Publishers, The Hague, p $219-225$

Kiorboe T, Nielsen TG (1994) Regulation of zooplankton biomass and production in a temperate, coastal system. 1 Copepods. Limnol Oceanogr 39:493-507

Klein Breteler WCM, Gonzalez SR (1982) Influence of cultivation and food concentration on body length of ralanoid copepods. Mar Biol 71:157-161

Klein Breteler WCM, Gonzalez SR (1988) Influence of temperature and food concentration on body size, weight and lipid content of two calanoid copepod species. Hydrobiologia 167/168:201-210

Kleppel GS (1992) Environmental regulation of feeding and egg production by Acartia tonsa off southern California. Mar Biol 112:57-65

Lam-Hoai T (1.985) Évolution saisonnière du zooplancton dans trois sites peu profonds de Thau, une lagune nordméditerranéenne. Hydrobiologia 128:161-174

Landry MR, Peterson WK, Fagerness VL (1994) Mesozooplankton grazing in the Southern California Bight. I. Population abundances and gut pigment contents. Mar Ecol Prog Ser 115:73-85

Landry MR, Peterson WK, Lorenzen CJ (1995) Zooplankton grazing, phytoplankton growth, and export flux: inferences from chlorophyll tracer methods. ICES J Mar Scl 52:337-345

Lonsdale DJ, Cosper EM, Kim WS, Doall M, Divadeenam A, Jonasdottir SH (1996) Food web interactions in the plankton of Long Islands bays, with the preliminary observations on brown tide effects. Mar Ecol Prog Ser 134: $247-263$

Lorenzen CJ (1967) Determination of chlorophyll and phaeopigments by spectrophotometric equations. Limnol Oceanogr 12:343-346

Madariaga I de, Conzález-Azpiri L, Villate F, Orive E (1992) Plankton responses to hydrological changes induced by freshets in a shallow mesotidal estuary. Estuar Coast Shelf Sci 35:425-434

Ohman MD, Aksnes DL, Runge JA (1996) The interrelationship of copepod fecundity and mortality. Limnol Oceanogr 41:1470-1477

Omori M, Ikeda I (1984) Methods in marine zooplankton ecology. John Wiley \& Sons, New York

Peterson DH, Festa JF (1984) Numerical simulation of phytoplankton productivity in partially mixed estuanes. Estuar Coast Shelf Sci 19:563-589

Peterson WT (1985) Abundance, age structure and in situ 
production rates of the copepod Temora longicornis in Long Island Sound, New York. Bull Mar Sci 37: $726-738$

Prestidge MC, Harris RP, Taylor AH (1995) A modelling investigation of copepod egg production in the Irish Sea. ICES J Mar Sci 52:693-703

Rodriguez V. Guerrero F, Bautista B (1995) Egg production of individual copepods of Acartia grani Sars from coastal waters: seasonal and diel variability. J Plankton Res 17: 2233-2250

San Vicente C, Miner A, D'Elbée J, Ibañez M (1988) Estudio de las rías guipuzcoanas.1 Primeros datos sobre el estudio de la ría de Orio. Lurralde 11:179-199

Sautour B, Castel J (1995) Comparative spring distribution of zooplankton in three macrotidal European estuaries. Hydrobiologia 311:139-151

Sekiguchi H, McLaren IA, Corkett CJ (1980) Relationship between growth rate and egg production in the copepod Acartia clausi hudsonica. Mar Biol 58:133-138

Smith SL, Lane PVZ (1985) Laboratory studies of the marine copepod Centropages typicus: egg production and development rates. Mar Biol 85:153-162

Stoecker DK, Egloff DA (1987) Predation by Acartia tonsa Dana on planktonic ciliates and rotifers. J Exp Mar Biol Ecol 110:53-68

Stoecker DK, Sanders NK (1985) Differential grazing by Acartia tonsa on a dinoflagellate and a tintinnid. J Plankton Res 7:85-100

Taylor CJL (1987) The zooplankton of the Forth, Scotland. Proc R Soc Edinb Sect B (Biol Sci) 93:377-388

Thompson AM, Durbin EG, Durbin AG (1994) Seasonal changes in maximum ingestion rate of Acartia tonsa in Narragansett Bay, Rhode Island, USA. Mar Ecol Prog Ser 107:91-105

Uye $S$ (1981j Fecunaity studies of nentıc calanord copepods Acartia clausi Giesbrecht and A. steueri Smirnov: a simple empirical model of daily egg production. J Exp Mar Biol Ecol 50:255-271

Uye S, Shibuno N (1992) Reproductive biology of the plank-

Editorial responsibility: Otto Kinne (Editor),

Oldendorf/Luhe, Germany tonic copepod Paracalanus sp. in the Inland Sea of Japan. J Plankton Res 14:343-358

Vitasalo M (1992a) Mesozooplankton of the Gulf of Finland and Northern Baltic Proper-a review of monitoring data. Ophelia 35:147-168

Viitasalo M (1992b) Calanoid resting eggs in the Baltic Sea: implications for the population dynamics of Acartia bifilosa (Copepoda). Mar Biol 114:397-405

Viitasalo M, Koski M, Pellikka K, Johansson S (1995) Seasonal and long-term variations in the body size of planktonic copepods in the northern Baltic Sea. Mar Biol 123:241-250

Villate F (1991) Zooplankton assemblages in the shallow tidal estuary of Mundaka (Bay of Biscay). Cah Bıol Mar 32: $105-119$

Villate F, Franco J, Ruiz A, Orive E (1989) Caracterización geomorfológica e hidrológica de cinco sistemas estuáricos del País Vasco. Kobie 18:157-170

Villate F, Orive E (1981) Copépodos planctónicos del estuario de Plencia: composición, distribución y abundancia. Munibe 33:87-100

Villate F, Ruiz A, Franco J (1993) Summer zonation and development of zooplankton populations within a shallow mesotidal system: the estuary of Mundaka. Cah Biol Mar 34:131-143

White JR, Roman MR (1992) Egg production by the calanoid copepod Acartia tonsa in the mesohaline Chesapeake Bay: the importance of food resources and temperature. Mar Ecol Prog Ser 86:239-249

Wiadnyana NN, Rassoulzadegan F (1989) Selective feeding of Acartia clausi and Centropages typicus on microzooplankton. Mar Ecol Prog Ser 53:37-45

Wlodarczyk E, Durbin AG, Durbin EG (1992) Effect of temperature on lower feeding thresholds, gut evacuation rate, and feeding behavior in the copepod Acartia hudsonica. Mar Ecol Prog Ser 85:93-106

Zhang $X$, Dam HG, White JR, Roman MR (1995) Latitudinal variations in mesozooplankton grazing and metabolism in the central tropical Pacific during the US JGOFS Eq Pac study. Deep Sea Res II 42:695-714

Submitted: October 27, 1997; Accepted: March 9, 1998

Proofs received from author(s): April 20,1998 